\title{
Bulk buying
}

William C. Nugent, MD

Stephen K. Plume, MD

See related article on page 53

From the Section of Cardiothoracic Surgery, Dartmouth-Hitchcock Medical Center, Lebanon, $\mathrm{NH}$, and the Dartmouth Medical School, Hanover, NH.

Received for publication April 2, 2001; accepted for publication April 12, 2001

Address for reprints: William C. Nugent, MD, Department of Cardiothoracic Surgery, Dartmouth-Hitchcock Medical Center, One Medical Center Dr, Lebanon, NH 03756.

J Thorac Cardiovasc Surg 2001;122:6-7

Copyright (C) 2001 by The American Association for Thoracic Surgery

0022-5223/2001 $\$ 35.00+0 \quad \mathbf{1 2 / 1 / 1 1 6 4 6 9}$

doi:10.1067/mtc.2001.116469

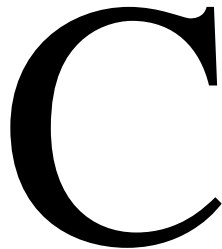

onventional wisdom holds that the quality of coronary artery bypass graft $(\mathrm{CABG})$ operations is higher, and the unit cost lower, if performed by high-volume surgeons in high-volume institutions. This belief has led some health care policy advisors, insurance purchasers, and hospital marketers to urge the public to choose surgeons or institutions on the basis of the numbers of cases done annually.

For example, the most recent "Consumers' Guide to Cardiac Surgery in Pennsylvania" advises readers that a surgeon's case volume is an important determinant of risk of perioperative mortality, but it does not specify the magnitude of the effect. ${ }^{1}$ It is surprising how weak this association is. Linear regression of case-mix-adjusted data in this report shows that about $10 \%$ of the observed variation in surgeonspecific mortality rates is attributable to a case volume effect. The same data set shows no relationship between volume and outcome at the hospital level. The most recent publicly available data from New York document a shrinking volume/mortality rate relationship. ${ }^{2,3}$ Case-mix-adjusted, institution-specific, Medicare beneficiary CABG mortality rates from a popular Web site ${ }^{4}$ show no volume/outcome correlation in the 6 New England states. The Northern New England Cardiovascular Disease Study Group has been unable to document any relationship between volume and outcome for patients undergoing CABG in Maine, New Hampshire, and Vermont for the past 6 years.

Quality of clinical outcome is only part of the value equation for patients having CABG. Shahian, Heatley, and Westcott ${ }^{5}$ carefully document in this issue of the Journal that there is currently no detectable relationship between unit cost and case volume among hospitals performing CABG in Massachusetts. This finding will be questioned, because it contradicts conventional wisdom. Critics may argue that using hospital charges in the formula to determine cost of CABG introduces a number more reflective of what the local market bears than the actual dollars spent in providing a service. However, market pressures are a reality of a free market economy, as is the regional nature of how those services are provided. The "cost" of a CABG in southern California is a meaningless concept to patients seeking care in Massachusetts. Others might argue that conclusions drawn from the small and homogeneous Massachusetts marketplace cannot be generalized. In fact, the homogeneity of the studied group serves as an asset for discovering or, as in this case, discarding a putatively causative variable. Geographic variations in how health care is delivered mandate that they be studied in regional units. From our patients' perspective, it is more important to understand whether there is a volume effect within a regional market than whether there are differences among regional markets.

We owe thanks to Shahian, Heatley, and Westcott for casting new light on a mistaken element of the conventional volume dictum and for using a meaningful regional analysis to describe this finding. It is increasingly clear that aggregate proxy measures like case volume contribute little to our understanding of the determinants of outcome. Our obligation is to improve the value of our work by reducing mortality and morbidity rates and by eliminating wasteful practices, regardless of current results and regardless of the size of our individual practices or institu- 
tional programs. We must continue to concentrate our efforts on understanding what causal elements of process specifically relate to the outcomes that are important to our patients.

\section{References}

1. A Consumer Guide to Coronary Artery Bypass Graft Surgery. Harrisburg (PA): Health Care Cost Containment Council; 19941995.
2. Hannan EL, O’Donnell JF, Bernard H, O'Donnell JF, Lukacik G, Shields EP. Coronary artery bypass surgery: the relationship between inhospital mortality rate and surgical volume after controlling for clinical risk factors. Med Care. 1991;29:1094-107.

3. Hannan EL. The relation between volume and outcome in health care. N Engl J Med. 1999;340:1677-9.

4. http://www.healthgrades.com/public/.

5. Shahian DM, Heatley GJ, Westcott GA. Relationship of hospital size, case volume, and cost for coronary artery bypass surgery: analysis of 12,774 patients operated on in Massachusetts during fiscal years 1995 and 1996. J Thorac Cardiovasc Surg. 2001;122:53-64.

Access to The Journal of Thoracic and Cardiovascular Surgery Online is reserved for print subscribers!

Full-text access to The Journal of Thoracic and Cardiovascular Surgery Online is available for all print subscribers. To activate your individual online subscription, please visit The Journal of Thoracic and Cardiovascular Surgery Online, point your browser to http://www.mosby.com/jtcvs, follow the prompts to activate your online access, and follow the instructions. To activate your account, you will need your subscriber account number, which you can find on your mailing label (note: the number of digits in your subscriber account number varies from 6 to 10). See the example below in which the subscriber account number has been circled:

Sample mailing label

\begin{tabular}{l|l|}
\cline { 2 - 2 } $\begin{array}{l}\text { This is your subscription } \\
\text { account number }\end{array}$ & $\begin{array}{l}* * * * * * * * * * * * * * * * * * * * * * * * * * 3-D I G I T \\
\text { SJ P1 }\end{array}$ \\
FEB00 J027 C: 1 1234567-89 U 05/00 Q: 1 \\
J. H. DOE, MD \\
531 MAIN ST \\
CENTER CITY, NY 10001-001 \\
\hline
\end{tabular}

Personal subscriptions to The Journal of Thoracic and Cardiovascular Surgery Online are for individual use only and may not be transferred. Use of The Journal of Thoracic and Cardiovascular Surgery Online is subject to agreement to the terms and conditions as indicated online. 